\title{
Use of Sodium Glucose Co-Transporter 2 Inhibitor (SGLT2i) in Geriatric Population
}

\author{
Işılay TAŞKALDIRAN ${ }^{1} \oplus \bowtie$, Şerife Mehlika KUŞKONMAZ ${ }^{2} \oplus$ Cavit CULHA $^{2}$ ๑ \\ ${ }^{1}$ Zonguldak Atatürk Public Hospital, Department of Endocrinology and Metabolism, Zonguldak, Turkey \\ ${ }^{2}$ Ankara Training and Research Hospital, Department of Endocrinology and Metabolism, Ankara, Turkey
}

Cite this article as: Taşkaldıran I et al. Use of Sodium-Glucose Cotransporter 2 Inhibitor (SGLT2i) in Geriatric Population. Turk J Diab Obes 2021;2: 158-164.

\begin{abstract}
Aim: Diabetes treatment and follow-up is more difficult and sensitive in the elderly. Sodium glucose co-transporter type 2 (SGLT2) inhibitors are newly developed antidiabetic agents. In the geriatric age group, the use of SGLT2 inhibitors may be riskier in terms of side effects. We planned to evaluate the effect and tolerability of using SGLT2 inhibitors in geriatric patients.

Material and Methods: Patients over 65 years of age with a diagnosis of type 2 DM who were started on empagliflozin or dapagliflozin in our center were included in the study. A total of 52 patients were included in the study. The study was designed as a retrospective file scan. Before and after SGLT2 inhibitor treatment, biochemical data, drug-related side effects and drug withdrawal information were recorded.

Results: A statistically significant decrease was observed in the fasting blood glucose (FBG), postprandial blood glucose (PPBG), and HbA1c values of the patients after the SGLT2 inhibitor was started. While the urea and creatinine values of the patients increased after the treatment, a decrease was observed in the eGFR value. After treatment, a decrease in albumin/creatinine ratio in spot urine and an increase in hemoglobin and hematocrit values were observed. No complaints were reported in 31 patients (59.6\%) and no side effects were detected. Side effects associated with SGLT2 inhibitor were observed in 21 patients (40.3\%). In total, treatment was continued in 41 patients $(78.8 \%)$ out of 52 patients, while treatment was discontinued in 11 patients $(21.2 \%)$.

Conclusion: In type 2 DM population over 65 years of age, glycemic control with SGLT 2 inhibitor treatment is successful, side effects and drug withdrawal rates are within acceptable limits.
\end{abstract}

Keywords: Elderly, Diabetes mellitus, SGLT2 inhibitor

\section{Geriatrik Popülasyonda Sodyum Glukoz Ko-Transporter 2 İnhibitörü(SGLT2i) Kullanımı}

ÖZ

Amaç: Yaşlılarda diyabet tedavisi ve takibi daha zor ve hassastır. Sodyum glukoz ko-transporter tip 2 (SGLT2) inhibitörleri yeni geliştirilmiş antidiyabetik ajanlardır. Geriatrik yaş grubunda, SGLT2 inhibitörlerinin kullanımı yan etkileri açısından daha riskli olabilir. Biz SGLT2 inhibitörlerinin geriatrik yaş grubunda kullanılmasının hastalardaki etkinliğini ve tolerabilitesini değerlendirmeyi planladık. Gereç ve Yöntemler: Çalışmaya, merkezimizde tip 2 DM tanısı ile empagliflozin veya dapagliflozin tedavisi başlanmış 65 yaş üstü hastalar alındı. Çalışmaya toplam 52 hasta dahil edildi. Çalışma retrospektif dosya tarama olarak dizayn edildi. SGLT2 inhibitörü tedavisi öncesi ve sonrası biyokimyasal veriler ve ilaca bağlı yan etkiler ve ilaç kesilme bilgileri kaydedildi.

Bulgular: Hastaların SGLT2 inhibitörü başlandıktan sonra açlık kan şekeri (AKŞ), tokluk kan şekeri (TKŞ), ve HbA1c değerlerinde istatistiksel olarak anlamlı derecede azalma izlendi. Hastaların üre ve kreatinin değerlerinde tedavi sonrası artış izlenirken, eGFR değerinde düşme izlendi. Tedavi sonrası spot idrarda albümin/kreatinin oranında azalma, hemoglobin ve hematokrit değerlerinde artı̧ izlendi. 31 hastada $(\% 59,6)$ hiçbir şikâyet bildirilmemiş ve yan etki saptanmamıştır. 21 hastada $(\% 40,3)$ SGLT2 inhibitörü ile ilişkili

ORCID: Işılay Taşkaldıran 0000-0002-1390-7571, Şerife Mehlika Kuşkonmaz 0000-0002-2602-1657, Cavit Culha / 0000-0002-9275-2538 
olduğu düşünülen yan etkiler izlenmiştir. Toplamda 52 hastadan 41 hastada $(\% 78,8)$ tedaviye devam edilirken, 11 hastada $(\% 21,2)$ tedavi kesilmiştir.

Sonuç: 65 yaş üstü tip 2 diyabet hastalarında SGLT 2 inhibitörü tedavisi ile glisemik kontrol başarılıdır, yan etkileri ve ilaç kesilme oranları kabul edilebilir sinırlardadır.

Anahtar Sözcükler: Yaşl, Diyabetes mellitus, SGLT2 inhibitörü

\section{INTRODUCTION}

Type 2 Diabetes Mellitus (DM) is a chronic disease with an increasing prevalence worldwide which causes significant mortality and morbidity especially in the elderly population (1). The treatment and follow-up of diabetes in the elderly is more difficult due to accompanying comorbidities, cognitive impairment, polypharmacy, side effects and interactions of medicines. Besides, the risk of hypoglycemia is higher in the elderly $(2,3)$.

Sodium glucose co-transporter type 2 (SGLT2) inhibitors are novel antidiabetic agents. SGLT2 inhibitors reduce plasma glucose levels by reducing renal reabsorption of glucose and increasing urinary glucose excretion, independently of insulin release and its effect (4). SGLT2 inhibitor treatment has been shown to have additional benefits such as weight loss, renoprotective and cardioprotective effects. However, it has some side effects like urogenital tract infection, fluid loss, and renal failure (5).

Considering the fragility of the geriatric age group, it can be considered that SGLT2 inhibitors are riskier in terms of side effects. Studies conducted in our country on the use of SGLT2 inhibitors in the geriatric population are limited. In this study, we aimed to evaluate the efficacy, side effects and safety of using SGLT2 Inhibitors in the geriatric age group in our clinic.

\section{MATERIALS and METHODS}

Patients over 65 years of age who were admitted to the endocrinology outpatient clinic with the diagnosis of type $2 \mathrm{DM}$ and started empagliflozin or dapagliflozin treatments were included in the study. The patients were determined by scanning electronic patient records using ICD (International Classification of Diseases) codes. Patient records were evaluated retrospectively between October 2020 and February 2021. 94 patients over 65 years of age who were started on SGLT2 inhibitors were screened. 18 patients were excluded from the study due to incomplete initial or control HbAlc, glucose, or other laboratory and clinical information. 24 patients were excluded from the study who did not come for control within 3-6 months after the initiation of SGLT2 inhibitor. Patients who had been taking SGLT2 inhibitors for at least 3 months were included. Consequently 52 patients in total were included in the study.
Patients were diagnosed with genital and urinary tract infections according to the ICD codes and prescribed antibiotics and antifungals, the history recorded, physical examination findings, and the results of the urinalysis and urine culture. Estimated Glomerular Filtration Rate (eGFR) was calculated with the Modification of Diet in Renal Diseases Study formula (MDRD). Renal failure was defined as $>30 \%$ decrease in eGFR value and/or eGFR $<60 \mathrm{~mL} / \mathrm{min} / 1.73 \mathrm{~m}^{2}$. Severe hypoglycemia; hypoglycemia requiring help or a serum glucose reading of $54 \mathrm{mg} / \mathrm{dl}$ and severe hyponatremia; was defined as hyponatremia with $\mathrm{Na}<125 \mathrm{mEq} / \mathrm{L}$ and clinical finding.

The demographic information, FBG, PPBG, HbA1c, liver enzymes and kidney function tests, complete urinalysis, serum lipids, protein excretion in spot urine were recorded routinely before and after the initiation of SGLT2 inhibitor. Besides, information on whether the patient developed side effects after the SGLT2 inhibitor and whether the drug was discontinued was recorded from the file info. Our study was approved by Ankara Training and Research Hospital Ethics Committee. (Decision dated 17.09.2020, Approval Number E-20-373)

\section{Statistical Analysis}

IBM SPSS 18.0 program for Windows was used for statistical analysis. All data were divided as categorical and numerical. Number and percentage values were used in categorical data. Normal distribution was evaluated by Shapiro-Wilk test. The mean \pm standard deviation (SD) was used for normally distributed variables. Paired sample $t$ test was used for the comparison of variables before and after the treatment. $P$ value $<0.05$ was considered statistically significant. Independent samples $t$ test was used in group comparison.

\section{RESULTS}

\section{Features of Patients}

52 patients were included in the study. 34 (65.4\%) patients were female, 18 (34.6\%) were male. The mean age was 69.7 \pm 3.8 (65-84). The duration of SGLT2 inhibitor use was ranged between 6.1-9 months, mean 6,1 months. The mean duration of diabetes was $15.6 \pm 7.3$ years (Table 1 ). 
Empagliflozin was initiated in 28 patients (53.8\%) and dapagliflozin was given to 24 patients $(46.2 \%)$. Basal insulin therapy was also initiated in 4 patients, and the dosage of insulin was increased in 3 patients, reduced in 5 patients. Besides, sitagliptin was initiated in 2 patients along with SGLT inhibitor and vildagliptin was initiated in 1 patient. Diabetes complications, accompanying comorbidities and previous treatments are shown in the Table 1.

\section{Laboratory Results of Patients}

Biochemical parameters checked before and after SGLT2 inhibitor treatment was initiated are shown in Table 2. A statistically significant decrease after the SGLT2 inhibitor was initiated was observed in FBG, PPBG, and HbAlc values $(\mathrm{p}=0.001, \mathrm{p}=0.022, \mathrm{p}=0.001$, respectively). Although the urea and creatinine values of the patients increased after the treatment, a decrease in the eGFR was observed. Among these changes, the increase in creatinine $(p=0.040)$ and the decrease in GFR ( $p=0.010$ ) were found to be statistically significant. After the treatment, there was a decrease in the albumin/creatinine ratio in spot urine, but this decrease was not statistically significant ( $\mathrm{p}=0.056$ ). Hemoglobin and hematocrit values of the patients were increased after SGLT2 inhibitor was initiated ( $\mathrm{p}=0.048, \mathrm{p}=0.004$, respectively).

\section{Side Effects of SGLT2 Inhibitors}

In 31 patients (59.6\%) no complaints were reported and no side effects were found. Side effects observed in 21 patients (40.3\%) that were thought to be related to the SGLT2 inhibitor are summarized in Table 3. Genital infection was detected in four patients (7.6\%), the treatment was discontinued in 2 of these patients, and continued in the others. Urinary
Table 1: Characteristics of patients.

\begin{tabular}{lc}
\hline Parameters & Values \\
\hline Age (Year \pm SD) & $69.7 \pm 3.8$ \\
\hline Gender, $\mathrm{n}(\%)$ & \\
Female & $34(65.4)$ \\
Male) & $18(34.6)$ \\
\hline Diabetes duration (Year \pm SD) & $15.6 \pm 7.3$ \\
\hline SGLT2 inhibitor, $\mathrm{n}(\%)$ & \\
Empagliflozin & $28(53.8)$ \\
Dapagliflozin & $24(46.2)$ \\
\hline Complications of diabetes, $\mathrm{n}(\%)$ & \\
Diabetic retinopathy & $6(11.5)$ \\
Diabetic nephropathy & $10(19.2)$ \\
Diabetic neuropathy & $18(34.6)$ \\
\hline Comorbidities, $\mathrm{n}(\%)$ & \\
Hypertension & $44(84.6)$ \\
Hyperlipidemia & $23(44.2)$ \\
Coronary artery disease & $22(42.3)$ \\
Heart failure & $3(5.8)$ \\
Past cerebrovascular event & $2(3.8)$ \\
\hline The other treatments, $\mathrm{n}(\%)$ & \\
Oral antidiabetic & $22(42.3)$ \\
Insulin and oral antidiabetic & $21(40.3)$ \\
Insulin, & $2(3.8)$ \\
Oral antidiabetic, insulin and GLP-1 & $4(7.7)$ \\
analog & $2(3.8)$ \\
Oral antidiabetic and GLP-1 analog & $1(1.9)$ \\
Not receiving treatment &
\end{tabular}

SGLT2: Sodium glucose co-transporter type 2, GLP: Glucagon-like peptide-1

Table 2: Laboratory changes before and after SGLT2 inhibitor therapy.

\begin{tabular}{lccc}
\hline Laboratory changes & $\begin{array}{c}\text { SGLT2 inhibitor } \\
\text { before }\end{array}$ & $\begin{array}{c}\text { SGLT2 inhibitor } \\
\text { after }\end{array}$ & p value \\
\hline Fasting blood glucose $(\mathrm{mg} / \mathrm{dL} \pm \mathrm{SD})$ & $196.2 \pm 55.2$ & $159.3 \pm 42.9$ & 0.001 \\
\hline Postprandial blood glucose $(\mathrm{mg} / \mathrm{dL} \pm \mathrm{SD})$ & $282.5 \pm 83.4$ & $243.6 \pm 71.6$ & 0.022 \\
\hline HbA1c $(\% \pm \mathrm{SD})$ & $9.1 \pm 1.5$ & $7.8 \pm 0.7$ & 0.001 \\
\hline Urea $(\mathrm{mg} / \mathrm{dL} \pm \mathrm{SD})$ & $36.2 \pm 8.0$ & $38.0 \pm 10.0$ & 0.384 \\
\hline Creatinine $(\mathrm{mg} / \mathrm{dL} \pm \mathrm{SD})$ & $0.7 \pm 0.1$ & $0.8 \pm 0.2$ & 0.040 \\
\hline eGFR $\left(\mathrm{mL} / \mathrm{min} / 1.73 \mathrm{~m}^{2} \pm \mathrm{SD}\right)$ & $82.8 \pm 11.9$ & $78.9 \pm 16.8$ & 0.010 \\
\hline Spot Urine $(\mathrm{Albumin} / \mathrm{creatinine} \mathrm{ratio} \pm \mathrm{SD})$ & $144.3 \pm 222.2$ & $113.7 \pm 174.7$ & 0.056 \\
\hline Hemoglobin $(\mathrm{g} / \mathrm{dL} \pm \mathrm{SD})$ & $13.8 \pm 1.4$ & $14.2 \pm 1.3$ & 0.048 \\
\hline Hematocrit $(\% \pm \mathrm{SD})$ & $42.9 \pm 3.6$ & $44.4 \pm 3.5$ & 0.004 \\
\hline
\end{tabular}

SGLT2: Sodium glucose co-transporter type 2, HbA1c: Glycolized hemoglobin, eGFR: Estimated glomerular filtration rate 
Table 3: Adverse events during SGLT2 inhibitor use

\begin{tabular}{lccc}
\hline Adverse events, $\mathbf{n}(\mathbf{\%})$ & Female $(\mathbf{n}=\mathbf{3 4})$ & Male $(\mathbf{n}=\mathbf{1 8})$ & Total $(\mathbf{n}=\mathbf{5 2})$ \\
\hline Urinary tract infection & $5(9.6)$ & $1(1.9)$ & $6(11.5)$ \\
\hline Genital infection & $3(5.7)$ & $1(1.9)$ & $4(7.6)$ \\
\hline Renal failure & $1(1.9)$ & $2(3.8)$ & $3(5.7)$ \\
\hline Ketonuria, & $2(3.8)$ & $0(0.0)$ & $2(3.8)$ \\
\hline Non-severe hypoglycemia & $0(0.0)$ & $2(3.8)$ & $2(3.8)$ \\
\hline Hypotension & $1(1.9)$ & $0(0.0)$ & $1(1.9)$ \\
\hline Hyponatremia & $0(0.0)$ & $1(1.9)$ & $1(1.9)$ \\
\hline Pollakiuria & $0(0.0)$ & $2(3.8)$ & $2(3.8)$ \\
\hline
\end{tabular}

tract infection was detected in 6 patients $(11.5 \%)$, the treatment was discontinued in half of them and continued in the other half. Treatment was discontinued in three patients (5.7\%) due to worsening of renal function tests. Ketonuria was observed in two patients $(3.8 \%)$ and treatment was discontinued. Non-severe hypoglycemia was reported in two patients (3.8\%), who also had been taking insulin, and SGLT inhibitor treatment was continued. Treatment was discontinued in one patient (1.9\%) due to hypotension. Asymptomatic mild hyponatremia (Na: $131 \mathrm{mmol} / \mathrm{L}$ ) was observed in one patient $(1.9 \%)$ and treatment was continued. Two patients $(3.8 \%)$ defined pollakiuria and the treatment was continued. Ketoacidosis, thromboembolic event and osteoporotic fracture were not observed in any of the patients. Though treatment was continued in 41 patients (78.8\%), it was discontinued in 11 patients $(21.2 \%)$ in total.

The mean age of the patients whose treatment was discontinued for various reasons was $72(\mathrm{SD})$ and of those who continued was 69.1 (SD); the difference was not statistically significant $(\mathrm{p}=0.080)$. Similarly, the duration of diabetes was longer in the group whose treatment was discontinued (17.6 years and 15.1 years, respectively), and the difference was not significant $(\mathrm{p}=0.300)$.

\section{DISCUSSION}

In addition to glycemic control, SGLT2 inhibitors are oral antidiabetic agents that reduce the rate of hospitalization due to heart failure, decrease cardiovascular and all-cause mortality and have renoprotective effects, for these reasons they have been used increasingly in the treatment of diabetes $(4,5)$.

In this study, we evaluated both glycemic control, pre-treatment and post-treatment biochemical changes, treatment tolerability and adverse events in patients who applied to our hospital's endocrinology outpatient clinic, who were over 65 years of age, diagnosed with type $2 \mathrm{DM}$ and initiated SGLT2 inhibitor.
After the initiation of the SGLT2 inhibitor, significant decreases were observed in the fasting blood glucose, postprandial blood glucose and $\mathrm{HbAlc}$ values of the patients. A decrease of $1.3 \%$ was observed in the mean $\mathrm{HbAlc}$ values of the patients. Since this decrease in $\mathrm{HbAlc}$ value will correspond to a significant decrease in diabetic complications, it is also clinically important (6). In the studies, the decrease observed in $\mathrm{HbA} 1 \mathrm{c}$ value with SGLT2 inhibitor is on average $0.5-0.7 \%(4,7,8)$. The reasons for the greater change in the $\mathrm{HbAlc}$ value in our study: were not only adding SGLT inhibitor treatment was not the only intervention to our patients, but also adjusting other antidiabetic agents, and having high initial HbAlc values. In the DECLARE study, dapagliflozin was compared with placebo in 17.160 patients. The patients were grouped as $<65$ years, 65-75 years and $>75$ years and a statistically significant decrease in $\mathrm{HbAlc}$ was observed in the dapagliflozin group in all age groups comparing to the placebo group. The decrease in the $\mathrm{HbAlc}$ value was observed as $0.58 \%, 0.46 \%$, and $0.51 \%$ in age groups, respectively (9). In a comparative study of empagliflozin with placebo in a total of 110 patients, HbAlc values decreased by $1.1 \%$ and $1.2 \%$ in the groups $<65$ and $>65$, respectively (10). As a result, SGLT2 inhibitors seem to be effective in lowering $\mathrm{HbAlc}$ values in the geriatric group as with the 18-65 age group.

In our study, a decrease in spot urine albumin/creatinine level was observed in the patients, although it was not statistically significant. On the other hand, a statistically significant decrease was observed in the eGFR values. In the previous studies, the renoprotective effects of SGLT2 inhibitors could be observed. In the EMPA-REG study, empagliflozin reduced the progression to albuminuria by $38 \%$ (11), although canagliflozin reduced the progression to albuminuria by $27 \%$ in the CANVAS study (12). Dapagliflozin also reduced albuminuria in 24 -hour urine by $36 \%$ (13). Although some decrease in eGFR value was observed in the early period after the initiation of SGLT2 inhibitor, better 
preserved eGFR values were observed in the long term, independent from glycemic control (14). Similar to the literature, a decrease in the eGFR value was observed in the short term in geriatric patients included in our study, but the decrease in albuminuria was not statistically significant.

Studies have shown that SGLT2 inhibitors increase hemoglobin and hematocrit values (4). It has been shown that dapagliflozin exerts this effect by increasing hepcidin level (15), and empagliflozin increases hemoglobin and hematocrit values by increasing erythropoiesis (16). Although this result was evaluated positively in some studies as it may increase myocardial oxygenation (16), it also caused concern in terms of the risk of thrombosis and stroke (17). Similar to the literature, an increase in hemoglobin and hematocrit values was observed in our geriatric patients in our study. Research is ongoing on the different mechanisms of that increase.

21 patients $(40.3 \%)$ experienced various adverse events and treatment was discontinued in 11 patients (21.2\%). In the EMPA-REG study, when all age groups were discussed together, the rate of discontinuation of drugs due to side effects was found to be $17.3 \%$ in 4687 patients of all age groups who received empagliflozin; however, it was be $19.4 \%$ in 2333 patients who received placebo (4). Besides, subgroup analyses of the EMPA-REG study, which included a total of 7020 patients, were evaluated according to age groups of $<65,65-75$ and $>75$. The frequency of any adverse events and the discontinuation rate in the age group of $<65$, $65-75$ and $>75$ year-old was $89.1 \%$ and $14.4 \% ; 91.8 \%$, and $20.2 \% ; 90.8 \%$ and $24.3 \%$ respectively (18). The frequency of drug discontinuation due to side effects in geriatric diabetic patients included in our study was similar to the findings in the literature, but it was slightly higher when compared to the patients $<65$ year-old on the literature. This has been attributed to patients $>65$ year-old being more fragile.

No complicated urinary tract infection was observed in our study; however, the rate of simple urinary tract infection was $11.5 \%$, mostly in female patients. In a previous study, the rate of simple urinary tract infection was $18 \%$, regardless of age, and women constitute the majority (4). In a study evaluating the side effects of empagliflozin; in the empagliflozin group frequency of simple urinary tract infections was found to be $15.4 \%, 19.9 \%$ and $26.2 \%$, respectively, in age groups of $<65$ years, $65-75$ years and $>75$ years-old. In the placebo group, the rates were $15.7 \%, 20.4 \%$ and $24.1 \%$ for the same age groups, respectively (18). This result shows that the incidence of urinary tract infections increases with age, independent of SGLT2 inhibitors. In the literature, it has been shown that patients $>60$ are more susceptible to urinary tract infections (19). Similarly, in a study conducted with an elderly population, the frequency of urinary tract infections was found to be $1.8 \%$ in the dapagliflozin group and it was found to be $2 \%$ in the placebo group (9). According to these studies, no significant difference was observed in the frequency of urinary tract infections between geriatric patients taking SGLT2 inhibitors and placebo group. However, as the age increased, the frequency of urinary system infections increased in the patients.

In our study, genital infection occurred in 4 (7.6\%) patients. Genital infection, like urinary tract infection, was observed more frequently in women. In the comparative study of empagliflozin versus placebo, genital tract infection was $7 \%$ in the empagliflozin and $1.8 \%$ in the placebo group in patients $<65$ year-old; $5.8 \%$ in the empagliflozin and $2.1 \%$ in placebo group in the patients aged of 65-75 years; and $5.4 \%$ in the empagliflozin and $0.9 \%$ in the placebo group in patients $>75$ (18). The frequency of genital tract infection with dapagliflozin was observed as $1.0 \%$ in patients $>65$ years and $0.8 \%$ in patients $<65$ years (9). In studies, empagliflozin was observed to increase the frequency of genital tract infections in all age groups compared to the placebo group, but the prevalence of genital tract infections in patients over 65 years of age is not higher than the patients under 65 years of age.

In the general population, the frequency of worsening in renal function tests with empagliflozin was $5.2 \%$ (4), in another study it was $6.2 \%>65$ years and $4.6 \%<65$ years (18). In these studies no difference was observed in the frequency of worsening in renal functions between the patients who received SGLT2 inhibitor and those who did not (18). In our study, we observed worsening of renal function tests in 3 patients $(5.7 \%)$.

Although ketonuria was observed in 2 patients (3.8\%) in our patients, ketoacidosis was not observed in any of our patients. In the literature, the frequency of diabetic ketoacidosis varies between $0.1-0.3 \%$ in those taking SGLT2 inhibitors $(4,9,18)$. The patients $>65$ years have a high risk for hypoglycemia due to many reasons such as insulin use or renal dysfunction; moreover, hypoglycemia may cause more morbidity and mortality in the elderly population. Severe hypoglycemia was not observed in our patients. Our two patients who described hypoglycemia had also been using insulin together with SGLT2 inhibitor treatment. One patient (1.9\%) experienced hypotension, and the underlying cause was thought to be secondary to volume loss. Although the findings related to volume loss in the literature vary between $6.9 \%-8.0 \%$ in patients $>65$ years, the findings are similar to patients $>65$ years who do not take SGLT2 inhibitors. 
The limitations of the study are the lack of information about the blood pressure and weight changes of the patients, the inability of comparison with the population $<65$ years, and the inclusion of a low number of the patients.

\section{CONCLUSION}

Glycemic control was successfully achieved with SGLT2 inhibitor treatment in type $2 \mathrm{DM}$ population $>65$ years and data is similar to the population data $>65$ years in the literature. Side effects and discontinuation rates are similar to the literature data and are within acceptable limits. SGLT inhibitors remain an important antidiabetic agent that might be preferred also in the geriatric population.

Acknowledgment

None

\section{Author Contributions}

Opinion: Işılay Taşkaldıran, Şerife Mehlika Kuşkonmaz, Cavit Culha, Research and writing: Işılay Taşkaldıran, Critical approach: Işılay Taşkaldıran, Şerife Mehlika Kuşkonmaz, Cavit Culha.

\section{Conflict of Interest}

The authors declare no conflicts of interest for this study.

\section{Financial Support}

No financial support was received for the article.

\section{Ethical Approval}

Our study was approved by Ankara Training and Research Hospital Ethics Committee. (Decision dated 17.09.2020, Approval Number E-20-373)

Peer Review Process

Extremely peer-reviewed.

\section{REFERENCES}

1. American Diabetes Association. 12. Older adults: Standards of Medical Care in Diabetes-2019. Diabetes Care. 2019;42:S139-S147.

2. Kirkman MS, Briscoe VJ, Clark N, Florez H, Haas LB, Halter JB, Huang ES, Korytkowski MT, Munshi MN, Odegard PS, Pratley RE, Swift CS. Diabetes in older adults. Diabetes Care. 2012;35: 2650-2664.

3. Ito H, Omoto T, Abe M, Matsumoto S, Shinozaki M, Nishio S, Antoku S, Mifune M, Togane M. Relationships between the duration of illness and the current status of diabetes in elderly patients with type 2 diabetes mellitus. Geriatr Gerontol Int. 2017;17:24-30

4. Zinman B, Wanner C, Lachin JM, Fitchett D, Bluhmki E, Hantel S, Mattheus M, Devins T, Johansen OE, Woerle HJ, Broedl UC, Inzucchi SE; EMPA-REG OUTCOME Investigators. Empagliflozin, cardiovascular outcomes, and mortality in type 2 diabetes. N Engl J Med. 2015;373: 2117-2128.
5. Zelniker TA, Wiviott SD, Raz I, Im K, Goodrich EL, Bonaca MP, Mosenzon O, Kato ET, Cahn A, Furtado RHM, Bhatt DL, Leiter LA, McGuire DK, Wilding JPH, Sabatine MS. SGLT2 inhibitors for primary and secondary prevention of cardiovascular and renal outcomes in type 2 diabetes: A systematic review and meta-analysis of cardiovascular outcome trials. Lancet. 2019;393:31-39.

6. Stratton IM, Adler AI, Neil HA, Matthews DR, Manley SE, Cull CA, Hadden D, Turner RC, Holman RR. Association of glycaemia with macrovascular and microvascular complications of type 2 diabetes (UKPDS 35): Prospective observational study. BMJ. 2000;321:405-412.

7. Ferrannini E, Seman L, Seewaldt-Becker E, Hantel S, Pinnetti S, Woerle HJ. A PhaseIIb, randomized, placebo-controlled study of the SGLT2 inhibitor empagliflozin in patients with type 2 diabetes. Diabetes Obes Metab. 2013;15:721-728.

8. Häring HU, Merker L, Seewaldt-Becker E, Weimer M, Meinicke T, Broedl UC, Woerle HJ; EMPA-REG MET Trial Investigators. Empagliflozin as add-on to metformin in patients with type 2 diabetes: A 24-week, randomized, double-blind, placebocontrolled trial. Diabetes Care. 2014;37:1650-1659.

9. Cahn A, Mosenzon O, Wiviott SD, Rozenberg A, Yanuv I, Goodrich EL, Murphy SA, Bhatt DL, Leiter LA, McGuire DK, Wilding JPH, Gause-Nilsson IAM, Fredriksson M, Johansson PA, Langkilde AM, Sabatine MS, Raz I. Efficacy and safety of dapagliflozin in the elderly: Analysis from the DECLARETIMI 58 study. Diabetes Care. 2020;43(2):468-475.

10. Ito H, Matsumoto S, Izutsu T, Kusano E, Nishio S, Antoku S, Yamasaki T, Mori T, Togane M, Ando S, Tsugami E. Comparison of the changes in the factors associated with the renal prognosis of non-elderly and elderly subjects treated with empagliflozin- a retrospective observation study in Japanese patients with type 2 diabetes. Diabetes Metab Syndr Obes. 2019;12:1783-1794.

11. Wanner C, Inzucchi SE, Lachin JM, Fitchett D, von Eynatten M, Mattheus M, Johansen OE, Woerle HJ, Broedl UC, Zinman B; EMPA-REG OUTCOME Investigators. Empagliflozin and progression of kidney disease in type 2 diabetes. N Engl J Med. 2016;375:323-334.

12. Neal B, Perkovic V, Mahaffey KW, de Zeeuw D, Fulcher G, Erondu N, Shaw W, Law G, Desai M, Matthews DR; CANVAS Program Collaborative Group. Canagliflozin and cardiovascular and renal events in type 2 diabetes. Engl J Med. 2017;377(7):644-657.

13. Petrykiv SI, Laverman GD, de Zeeuw D, Heerspink HJL. The albuminuria-lowering response to dapagliflozin is variable and reproducible among individual patients. Diabetes Obes Metab. 2017;19:1363-1370.

14. Garofalo C, Borrelli S, Liberti ME, Andreucci M, Conte G, Minutolo R, Provenzano M, De Nicola L. SGLT2 inhibitors: nephroprotective efficacy and side effects. Medicina (Kaunas). 2019;55:268.

15. Ghanim H, Abuaysheh S, Hejna J, Green K, Batra M, Makdissi A, Chaudhuri A, Dandona P. Dapagliflozin suppresses hepcidin and increases erythropoiesis. J Clin Endocrinol Metab. 2020;105(4):dgaa057. 
16. Mazer CD, Hare GMT, Connelly PW, Gilbert RE, Shehata N, Quan A, Teoh H, Leiter LA, Zinman B, Jüni P, Zuo F, Mistry $\mathrm{N}$, Thorpe KE, Goldenberg RM, Yan AT, Connelly KA, Verma S. Effect of empagliflozin on erythropoietin levels, iron stores, and red blood cell morphology in patients with type 2 diabetes mellitus and coronary artery disease. Circulation. 2020;141:704-707.

17. Imprialos KP, Boutari C, Stavropoulos K, Doumas M, Karagiannis AI. Stroke paradox with SGLT-2 inhibitors: A play of chanceor a viscosity-mediatedreality? J Neurol Neuro surg Psychiatry. 2017;88:249-253.
18. Monteiro P, Bergenstal RM, Toural E, Inzucchi SE, Zinman B, Hantel S, Kiš SG, Kaspers S, George JT, Fitchett D. Efficacy and safety of empagliflozin in older patients in the EMPA-REG OUTCOME $^{\circledast}$ trial. Age Ageing. 2019;48(6):859-866.

19. Hirji I, Guo Z, Andersson SW, Hammar N, Gomez-Caminero A. Incidence of urinary tract infection among patients with type 2 diabetes in the UK General Practice Research Database (GPRD). J Diabetes Complications 2012;26: 513-516. 